\title{
POTENSI SALVINIA MOLESTA D.S. MITCHELL, LIMNOCHARIS FLAVA (L.) BUCHENAU DAN MONOCHORIA VAGINALIS (BURM.F.) PRESL UNTUK FITOEKSTRAKSI MERKURI DI SAWAH YANG TERCEMAR MERKURI AKIBAT KEGIATAN PENAMBANG EMAS TANPA IZIN (PETI)
}

\author{
Titi Juhaeti'1), Nuril Hidayati'1), Fauzia Syarif(1) dan Syamsul Hidayat ${ }^{2)}$ \\ Peneliti Pusat Penelitian Biologi LIPI'1) \\ Pusat Konservasi Tumbuhan Kebun Raya Bogor ${ }^{2)}$ \\ E-mail : tihaeti@yahoo.com
}

\begin{abstract}
The research were carried out to study the potency of Salvinia molesta D.S. Mitchell (Kiambang), Limnocharis flava (L.) Buchenau (Genjer) and Monochoria vaginalis (Burm.f.) Presl (Eceng) for $\mathrm{Hg}$ phytoextraction on paddy field contaminated with $\mathrm{Hg}$ from illegal mining. The plants were grown on contaminated media from paddy field in Pongkor (68.269 ppm Hg) added by NPK fertilizer (0, 3 and $6 \mathrm{~g} / \mathrm{pot}$ ) and ammonium thiosulphate chelating agent $(0,20 \mathrm{ppm})$. The result showed that the growth of kiambang, eceng, genjer and padi are significantly different. Chelating agent did not significantly affect the plant growth, meanwhile fertilizer significantly affected the plant growth. The treatments resulted in different $\mathrm{Hg}$ concentration in the plants. Fertilizer increased plant biomass and so plant $\mathrm{Hg}$ content since $\mathrm{Hg}$ contents is a function of total biomass and $\mathrm{Hg}$ concentration. It can be concluded that based on the criteria of accumulator plant, kiambang is the most potentially $\mathrm{Hg}$ accumulator followed by genjer and eceng.
\end{abstract}

Key words: Phytoextraction, Hg, Salvinia molesta, Limnocharis flava, Monochoria vaginalis

\section{PENDAHULUAN}

\subsection{Latar Belakang}

Kontaminasi logam berat dalam tanah merupakan masalah yang umum dijumpai di lingkungan sekitar kita seperti misalnya di lokasi penambangan emas tanpa izin (PETI) yang biasanya dilakukan oleh masyarakat setempat. Dalam mengekstrak emas, para penambang menggunakan merkuri yang pembuangan limbahnya tidak terkontrol. Limbah air dan sedimen dari para penambang masuk ke sungai, ke kolam, ke saluran air irigasi dan akhirnya ke sawah. Sebagai contoh, hasil pengamatan konsentrasi $\mathrm{Hg}$ di lumpur sawah di daerah Pongkor yang terletak di sekitar kegiatan
PETI dapat mencapai 68.269 ppm. Hasil analisa terhadap kandungan merkuri pada padi yang dihasilkan mencapai masingmasig di akar padi 0.258 ppm, tajuk padi $0.384 \mathrm{ppm}$ dan bulir padi $1.320 \mathrm{ppm}^{6}$.

Salah satu cara untuk mengatasi masalah pencemaran oleh logam berat adalah pembersihan logam kontaminan tersebut dengan menggunakan tumbuhan yang dikenal dengan istilah fitoremediasi. Fitoremediasi didefinisikan sebagai pencucian polutan yang dimediasi oleh tumbuhan berfotosintesis, termasuk pohon, rumput-rumputan dan tumbuhan air. Pencucian bisa berarti penghancuran, inaktivasi atau imobilisasi polutan ke 
bentuk yang tidak berbahaya. Model fitoremediasi dan beberapa jenis tumbuhan dapat direkomendasikan untuk digunakan secara efisien dalam membersihkan pencemar di areal pertanian ${ }^{5}$. Semula fungsi tumbuhan diketahui hanya untuk mengubah penutupan lahan, memperbaiki kualitas tanah dan mikroklimat dan pada akhirnya menumbuhkan produktivitas lahan terdegradasi bekas penambangan. Dalam penelitian fitoremediasi, fungsi-fungsi tumbuhan dipelajari secara lebih mendalam lagi yakni sebagai akumulator logam berat pencemar dalam tanah dan perairan di lingkungan penambangan.

Di Indonesia penelitian jenis-jenis tumbuhan untuk tujuan fitoremediasi pada umumnya dan untuk fitoremediasi merkuri secara khusus masih sangat terbatas. Sementara itu, Indonesia dengan kekayaan floranya diyakini memiliki banyak jenis yang potensial untuk digunakan dalam fitoremediasi. Diantaranya jenis potensial tersebut adalah tumbuhan yang tumbuh di sawah yang diduga bermanfaat untuk membersihkan polutan di sawah, diantaranya polutan berupa merkuri $(\mathrm{Hg})$. Tumbuhan yang tumbuh di sawah diantaranya Salvinia molesta D.S. Mitchell (kiambang), Limnocharis flava (L.) Buchenau (genjer) dan Monochoria vaginalis (Burm.f.) Presl (eceng). Di sawah-sawah di wilayah Pongkor yang kandungan $\mathrm{Hg}$ nya tinggi, kiambang, genjer dan eceng mampu tumbuh dengan baik. Hasil penelitian menunjukkan bahwa pada larutan Hoagland, kiambang mampu tumbuh baik bahkan sampai konsentrasi Hg mencapai 8 ppm apabila diberi kelat amonium tiosulfat ${ }^{6)}$.

Kunci keberhasilan praktek fitoremediasi adalah pada pemilihan jenis tanaman yang sesuai dan penerapan praktek-praktek agronomis serta pemberian perlakuan baik pada tanah maupun pada tanaman sesuai kebutuhan. Pengaturan praktek agronomi dilakukan diantaranya melalui pemberian pemupukan untuk meningkatkan produksi biomassa tanaman. Selain itu dapat pula dilakukan pemberian kelat yang dimaksudkan untuk meningkatkan daya serap logam. Pemberian kelat dalam tanah dapat memacu ketersediaan dan transfer logam dari akar ke tajuk. Dalam mekanisme pengkelatan, diyakini bahwa logam diserap tanaman dalam bentuk kompleks logam-kelat yang lebih mudah diserap akar dan ditranslokasi ke tajuk ${ }^{11)}$. Salah satu pendekatan untuk meningkatkan kemampuan tanaman dalam remediasi $\mathrm{Hg}$ adalah dengan penggunaan larutan non toksik yang mengandung tio untuk meningkatkan akumulasi $\mathrm{Hg}$. Ammonium thiosulfat merupakan kelat untuk $\mathrm{Hg}$, pemberian kelat tersebut berpengaruh terhadap serapan $\mathrm{Hg}$ oleh tanaman ${ }^{7}$. Kelat membentuk ikatan kompleks dengan merkuri sehingga menjadi bentuk yang kurang toksik dan lebih mudah diserap oleh tanaman.. Merkuri memiliki afinitas yang tinggi terhadap grup tiol dan dapat cepat membentuk komplek dengan ion tiosulfat ${ }^{8}$. Amonium tiosulfat $\left(\mathrm{NH}_{4}\right)_{2} \mathrm{~S}_{2} \mathrm{O}_{3}$ digunakan untuk merangsang Brassica juncea sehingga dapat mengakumulasi $\mathrm{Hg}$ sampai $40 \mathrm{mg}$ $\mathrm{Hg} / \mathrm{kg}$. Aplikasi $\left(\mathrm{NH}_{4}\right)_{2} \mathrm{~S}_{2} \mathrm{O}_{3}$ ke substrat meningkatkan sampai 6 kali konsentrasi $\mathrm{Hg}$ dalam tajuk dan akar Brassica juncea relatif terhadap kontrol. Jadi penambahan larutan tio efektif meningkatkan konsentrasi $\mathrm{Hg}$ di tajuk $^{9)}$.

\section{Tujuan}

Penelitian ini bertujuan untuk mengetahui pengaruh pemupukan dan pemberian kelat terhadap pertumbuhan dan serapan Hg pada Salvinia molesta D.S. Mitchell, (kiambang), Monochoria vaginalis (Burm.f.) Presl, (eceng) dan Limnocharis flava (L.) Buchenau (genjer) serta Oryza sativa (padi) sebagai pembanding untuk digunakan pada fitoremediasi $\mathrm{Hg}$ di lahan sawah. 


\section{METODE PENELITIAN}

Penelitian ini dilakukan di rumah kaca Puslit Biologi LIPI. Tanaman ditanam di pot-pot plastik dengan bobot media tanam $5 \mathrm{~kg} /$ pot. Media tanam yang digunakan berupa berupa lumpur sawah yang diambil dari sawah di Kampung Leuwi Bolang, desa Bantar Karet, Kec. Nanggung Bogor. Konsentrasi $\mathrm{Hg}$ di lumpur sawah tersebut adalah 68.269 ppm Hg,

Penelitian ini menggunakan Rancangan Acak lengkap yang disusun secara faktorial. Faktor-faktor perlakuannya adalah sebagai berikut:

1. Jenis tumbuhan: Salvinia molesta D.S. Mitchell (kiambang), Limnocharis flava (L.) Buchenau (genjer), Monochoria vaginalis (Burm.f.) Presl (eceng) dan Oryza sativa (padi). Untuk selanjutnya nama yang akan ditulis dalam naskah ini adalah kiambang, eceng, genjer dan padi.

2. Konsentrasi pupuk NPK (20-7-7): $0 \mathrm{~g} /$ pot, $3 \mathrm{~g} /$ pot dan $6 \mathrm{~g} / \mathrm{pot}$

3. Konsentrasi Kelat Amonium tiosulfat: 0 ppm, 20 ppm.

Perlakuan kelat dan pemupukan diberikan pada umur 1 bulan setelah tanam. Panen dilakukan pada umur 1 bulan setelah perlakuan, kecuali kiambang pada umur 2 minggu setelah perlakuan. Peubah yang diamati: Pertumbuhan tanaman meliputi tinggi tanaman dan jumlah daun (hanya dilakukan pada genjer, eceng dan padi), bobot basah total, bobot basah akar, bobot basah tajuk, bobot kering akar dan bobot kering tajuk serta serapan merkuri pada tajuk dan akar tanaman(untuk semua jenis tanaman yang diuji). Tinggi tanaman diukur dari mulai leher akar sampai ujung daun tertinggi. Jumlah daun yang dihitung adalah daun yang masih hidup menempel di tanaman. Analisa konsentrasi merkuri dalam tanaman dilakukan di LPT dengan menggunakan AAS metoda anhidrida.

\section{HASIL DAN PEMBAHASAN}

Pertumbuhan tanaman yang diamati adalah tinggi tanaman dan jumlah daun (untuk genjer, eceng dan padi), bobot basah total, bobot basah akar, bobot basah tajuk, bobot kering akar dan bobot kering tajuk (untuk kiambang, eceng, genjer dan padi).

Hasil pengamatan menunjukkan bahwa ke empat jenis tumbuhan yang diuji menunjukkan toleransi yang tinggi terhadap media tumbuhnya. Sesuai dengan perawakannya, pertumbuhan masing-masing jenis tanaman berbeda nyata. Untuk tinggi tanaman, padi menunjukkan ukuran yang tertinggi diikuti genjer dan eceng. Jumlah daun terbanyak pada eceng, genjer dan padi. Bobot basah tajuk, bobot basah akar, bobot kering tajuk dan bobot kering akar terbanyak pada kiambang. Hal ini menunjukkan pesatnya pertumbuhan kiambang, padahal jenis ini dipanen lebih cepat yakni 2 minggu setelah perlakuan, sedangkan jenis lain mencapai 1 bulan setelah perlakuan (Tabel 1).

Pengaruh pemberian kelat terhadap pertumbuhan tanaman tertera pada Tabel 2. Hasilnya menunjukkan bahwa pemberian kelat tidak berpengaruh nyata terhadap semua peubah pertumbuhan tanaman (Tabel 2 )

Tabel 1. Pertumbuhan masing-masing jenis tanaman

\begin{tabular}{|l|l|l|l|l|l|l|}
\hline \multicolumn{1}{|c|}{ Jenis } & \multicolumn{1}{c|}{ TT } & \multicolumn{1}{c|}{ JD } & \multicolumn{1}{c|}{ BBT (g) } & \multicolumn{1}{c|}{ BBA (g) } & \multicolumn{1}{c|}{ BKT (g) } & \multicolumn{1}{c|}{ BKA (g) } \\
\hline Kiambang & - & - & $122.217 \mathrm{a}$ & $22.90 \mathrm{a}$ & $6.87 \mathrm{a}$ & $1.90 \mathrm{a}$ \\
\hline Eceng & $26.031 \mathrm{~b}$ & $9.061 \mathrm{a}$ & $55.05 \mathrm{~b}$ & $22.22 \mathrm{a}$ & $3.64 \mathrm{c}$ & $1.11 \mathrm{~b}$ \\
\hline Genjer & $27.063 \mathrm{~b}$ & $5.808 \mathrm{~b}$ & $64.52 \mathrm{~b}$ & $16.69 \mathrm{~b}$ & $4.80 \mathrm{~b}$ & $1.28 \mathrm{~b}$ \\
\hline Padi & $52.064 \mathrm{a}$ & $5.239 \mathrm{~b}$ & $22.87 \mathrm{c}$ & $7.44 \mathrm{c}$ & $4.66 \mathrm{~b}$ & $0.98 \mathrm{~b}$ \\
\hline
\end{tabular}

Keterangan: Huruf yang sama pada kolom yang sama menunjukkan tidak beda nyata pada uji Duncan $5 \%$. TT=tinggi tanaman, JD=jumlah daun, BBT=bobot basah tajuk, BBA=bobot basah akar, BKT=bobot kering tajuk, BKA=bobot kering akar. 
Tabel 2. Pengaruh perlakuan kelat terhadap pertumbuhan tanaman.

\begin{tabular}{|l|c|c|c|c|c|c|}
\hline \multicolumn{1}{|c|}{ Perlakuan } & \multicolumn{1}{c|}{ TT } & \multicolumn{1}{c|}{ JD } & \multicolumn{1}{c|}{ BBT } & BBA & \multicolumn{1}{c|}{ BKT } & \multicolumn{1}{c|}{ BKA } \\
\hline Tanpa kelat & $35.319 \mathrm{a}$ & $6.706 \mathrm{a}$ & $62.53 \mathrm{a}$ & $17.12 \mathrm{a}$ & $4.91 \mathrm{a}$ & $1.35 \mathrm{a}$ \\
\hline Kelat & $34.293 \mathrm{a}$ & $6.742 \mathrm{a}$ & $70.80 \mathrm{a}$ & $17.72 \mathrm{a}$ & $5.08 \mathrm{a}$ & $1.30 \mathrm{a}$ \\
\hline
\end{tabular}

Keterangan: Huruf yang sama pada kolom yang sama menunjukkan tidak beda nyata pada uji Duncan $5 \%$.

Pemupukan Yang Diberikan Berpengaruh Nyata Terhadap Pertumbuhan Tinggi Tanaman, Jumlah Daun, Bobot Basah Tajuk Dan Bobot Kering Tajuk (Tabel 3). Pemupukan Pada Dosis $3 g$ Menunjukkan Hasil Tertinggi, Diikuti 6 G Dan Kontrol. Akan Tetapi Pemupukan Tidak Berpengaruh Nyata Terhadap Bobot Basah Akar Dan Bobot Kering Akar (Tabel 3).

\subsection{Pertumbuhan eceng (Monochoria vaginalis)}

Pada perlakuan tanpa pemberian kelat, pemupukan berpengaruh nyata terhadap tinggi tanaman dan bobot kering tajuk, tetapi tidak berbeda nyata terhadap jumlah daun dan bobot kering akar. Tinggi tanaman dan bobot kering tajuk tertinggi didapat pada

Tabel 3. Pengaruh perlakuan pemupukan terhadap pertumbuhan tanaman

\begin{tabular}{|l|l|l|l|l|l|l|}
\hline \multicolumn{1}{|c|}{ Perlakuan } & \multicolumn{1}{c|}{ TT } & \multicolumn{1}{c|}{ JD } & \multicolumn{1}{c|}{ BBT } & \multicolumn{1}{c|}{ BBA } & \multicolumn{1}{c|}{ BKT } & \multicolumn{1}{c|}{ BKA } \\
\hline Tanpa pupuk & $31.915 \mathrm{c}$ & $6.085 \mathrm{~b}$ & $53.73 \mathrm{~b}$ & $20.11 \mathrm{a}$ & $3.51 \mathrm{~b}$ & $1.29 \mathrm{a}$ \\
\hline $3 \mathrm{~g}$ & $37.775 \mathrm{a}$ & $7.272 \mathrm{a}$ & $79.46 \mathrm{a}$ & $16.06 \mathrm{a}$ & $5.85 \mathrm{a}$ & $1.39 \mathrm{a}$ \\
\hline $6 \mathrm{~g}$ & $34.747 \mathrm{~b}$ & $6.817 \mathrm{ab}$ & $66.68 \mathrm{ab}$ & $16.04 \mathrm{a}$ & $5.65 \mathrm{a}$ & $1.27 \mathrm{a}$ \\
\hline
\end{tabular}

Keterangan: Huruf yang sama pada kolom yang sama menunjukkan tidak beda nyata pada uji Duncan $5 \%$.

\subsection{Pertumbuhan Kiambang (Salvinia molesta)}

Kiambang menunjukkan pertumbuhan yang sangat cepat. Pada perlakuan tanpa pemberian kelat, pemupukan berpengaruh nyata terhadap bobot kering tajuk tanaman. Bobot kering tajuk tertinggi didapat pada perlakuan pemupukan $6 \mathrm{~g}(8.05 \mathrm{~g})$, diikuti pemupukan $3 \mathrm{~g}$ dan kontrol. Hal ini menunjukkan bahwa kiambang responsif terhadap pemupukan. Pada perlakuan dengan pemberian kelat, pemupukan juga berpengaruh nyata terhadap bobot kering tajuk tanaman, bobot kering tertinggi didapat pada perlakuan pemupukan $3 \mathrm{~g}(7.5 \mathrm{~g})$ diikuti dari perlakuan pemupukan $6 \mathrm{~g}$ dan kontrol (Tabel 4). Hal ini diduga terjadi karena kelat meningkatkan serapan $\mathrm{Hg}$ oleh tanaman sehingga terjadi penurunan pertumbuhan tanaman. perlakuan $3 \mathrm{~g}$ diikuti perlakuan $6 \mathrm{~g}$ dan kontrol. Nampaknya pemupukan dengan dosis $6 \mathrm{~g}$ ini sudah mengganggu pertumbuhan tanaman. Pada perlakuan dengan pemberian kelat, perlakuan pemupukan tidak berpengaruh nyata terhadap semua peubah pertumbuhan yang diamati (Tabel 4).

\subsection{Pertumbuhan Genjer (Limnocharis flava)}

Pada genjer tanpa pemberian kelat, perlakuan pemupukan tidak berpengaruh nyata terhadap semua peubah pertumbuhan yang diamati. Pada perlakuan dengan perlakuan kelat, pemupukan berpengaruh nyata terhadap tinggi tanaman, jumlah daun dan bobot kering tajuk, tetapi tidak berpengaruh nyata terhadap bobot kering akar (Tabel 4). Pada tinggi tanaman dan bobot kering tajuk, pemupukan $6 \mathrm{~g}$ tidak berbeda nyata dengan pemupukan $3 \mathrm{~g}$ 
tetapi berbeda nyata dengan kontrol. Perlakuan pemupukan $6 \mathrm{~g}$ menunjukkan tinggi tanaman, jumlah daun dan bobot kering tajuk tertinggi.

\subsection{Pertumbuhan Padi (Oryza sativa)}

Pada padi tanpa perlakuan kelat, pemupukan berpengaruh nyata terhadap tinggi tanaman, bobot kering tajuk and bobot kering akar. Nilai tertinggi dicapai pada perlakuan $3 \mathrm{~g}$, diikuti kontrol dan $6 \mathrm{~g}$. Pada perlakuan dengan pemberian kelat, pemupukan berpengaruh nyata terhadap tinggi tanaman dan jumlah daun tetapi tidak berpengaruh nyata terhadap bobot kering tajuk dan bobot kering akar, angka tertinggi diperoleh pada perlakuan $3 \mathrm{~g}$ diikuti 6 g dan kontrol (Tabel 4).

\subsection{Kandungan merkuri pada tanaman}

Tiap jenis tanaman mempunyai kemampuan yang berbeda dalam mengakumulasi $\mathrm{Hg}$. Tabel 5 menunjukkan konsentrasi $\mathrm{Hg}$ pada masing-masing jenis tanaman pada masing-masing perlakuan. Hasilnya menunjukkan bahwa masingmasing jenis tanaman memiliki kemampuan yang berbeda dalam mengakumulasi merkuri. Data menunjukkan bahwa kiambang memiliki potensi menyerap dan mengakumulasi $\mathrm{Hg}$ lebih tinggi dibanding eceng, genjer dan padi. Nilai ratio $\mathrm{Hg}$ di tajuk/akar pada kiambang juga rata-rata lebih besar dari satu. Nilai ratio $\mathrm{Hg}$ tajuk/akar ini sangat penting karena nilai ini menunjukkan akumulasi dan translokasi

Tabel 4. Pertumbuhan kiambang pada umur 2 minggu setelah perlakuan dan pertumbuhan eceng, genjer padi umur 1 bulan setelah perlakuan

\begin{tabular}{|c|c|c|c|c|c|c|c|}
\hline \multicolumn{2}{|c|}{ Perlakuan/peubah } & \multirow{2}{*}{$\begin{array}{l}\text { Tinggi } \\
\text { Tanaman } \\
\text { (cm) }\end{array}$} & \multirow[b]{2}{*}{ Jumlah Daun } & \multirow{2}{*}{$\begin{array}{c}\text { Bobot Basah } \\
\text { Tajuk (g) }\end{array}$} & \multirow{2}{*}{$\begin{array}{l}\text { Bobot Basah } \\
\text { Akar(g) }\end{array}$} & \multirow{2}{*}{$\begin{array}{c}\text { Bobot Ker- } \\
\text { ing Tajuk } \\
\text { (g) }\end{array}$} & \multirow{2}{*}{$\begin{array}{c}\text { Bobot Kering } \\
\text { Akar (g) }\end{array}$} \\
\hline Kelat (ppm) & Pupuk (g) & & & & & & \\
\hline \multicolumn{8}{|c|}{ KIAMBANG } \\
\hline 0 & P0 & - & - & $133.3 a$ & $32.63 a$ & $5.40 c$ & $1.95 a$ \\
\hline 0 & P3 & - & - & $120.43 a$ & $6.55 \mathrm{~b}$ & $7,13 b$ & $1,43 a$ \\
\hline 0 & P6 & - & - & $91,88 \mathrm{a}$ & $24,48 a b$ & $8,05 a$ & $2,25 a$ \\
\hline & & & & & & & \\
\hline 20 & P0 & - & - & $102,13 a$ & $44,13 a$ & $5,73 b$ & $2,03 a$ \\
\hline 20 & P3 & - & - & $169,75 a$ & $20,13 b$ & $7,50 a$ & $2,13 a$ \\
\hline 20 & P6 & - & - & $116,13 a$ & $9,50 \mathrm{~b}$ & $7,40 a$ & $1,60 a$ \\
\hline & & & & & & & \\
\hline \multicolumn{8}{|c|}{ ECENG } \\
\hline 0 & $\mathrm{P} 0$ & $21.800 \mathrm{~b}$ & $10.043 \mathrm{a}$ & $29.58 \mathrm{~b}$ & $20,03 a$ & $1,88 \mathrm{~b}$ & $1,03 a$ \\
\hline 0 & P3 & $28.063 \mathrm{a}$ & $10.375 a$ & $66,13 a$ & $22,65 a$ & $4,98 a$ & $1,15 a$ \\
\hline 0 & P6 & $27.125 \mathrm{a}$ & $7.625 \mathrm{a}$ & $44,10 \mathrm{ab}$ & $19 a$ & $2,95 b$ & $0,95 a$ \\
\hline & & & & & & & \\
\hline 20 & P0 & $28.325 \mathrm{a}$ & $7.325 a$ & $52,35 a$ & $23,73 a$ & $3,05 a$ & $1,18 a$ \\
\hline 20 & P3 & $28.975 a$ & $9.500 \mathrm{a}$ & $63,75 a$ & $20,45 a$ & $3,85 a$ & $0,93 a$ \\
\hline 20 & P6 & $21.900 \mathrm{a}$ & $9.500 \mathrm{a}$ & $74,40 a$ & $27,45 a$ & $5,15 a$ & $1,45 a$ \\
\hline \multicolumn{8}{|c|}{ GENJER } \\
\hline 0 & $\mathrm{P} 0$ & $24.228 \mathrm{a}$ & $4.800 \mathrm{a}$ & $54,88 a$ & $12,78 a$ & $2,40 a$ & $0,93 a$ \\
\hline 0 & P3 & $33.975 \mathrm{a}$ & $6.430 \mathrm{a}$ & $89,75 a$ & $26,95 a$ & $6,43 a$ & $2,03 a$ \\
\hline 0 & P6 & $24.775 a$ & $5.600 \mathrm{a}$ & $54,23 a$ & $17,20 a$ & $5,83 a$ & $1,30 a$ \\
\hline 20 & P0 & $21.520 \mathrm{~b}$ & $4.543 \mathrm{c}$ & $27,63 b$ & $14,68 a$ & $2,53 b$ & $1,48 a$ \\
\hline 20 & P3 & $28.125 \mathrm{a}$ & $6.075 \mathrm{~b}$ & $67,23 a$ & $14,73 a$ & $5,10 a$ & $1,15 a$ \\
\hline 20 & P6 & $29.758 \mathrm{a}$ & $7.400 \mathrm{a}$ & $93,44 a$ & $13,80 a$ & $6,55 a$ & $0.83 a$ \\
\hline & & & & & & & \\
\hline \multicolumn{8}{|c|}{ PAD I } \\
\hline 0 & $\mathrm{P} 0$ & $47.350 \mathrm{~b}$ & $5.050 \mathrm{a}$ & $13,58 \mathrm{~b}$ & $5,78 b$ & $3,20 \mathrm{~b}$ & $0,75 a$ \\
\hline 0 & P3 & $57.848 a$ & $5.125 \mathrm{a}$ & $36,50 a$ & $12,28 a$ & $7,55 a$ & $1,75 b$ \\
\hline 0 & P6 & $52.708 a$ & $5.300 \mathrm{a}$ & $16,38 \mathrm{~b}$ & $5,13 b$ & $3,20 \mathrm{~b}$ & $0,68 b$ \\
\hline 20 & P0 & $48.270 \mathrm{~b}$ & $4.750 \mathrm{~b}$ & $16,75 a$ & $7,13 a$ & $3,30 a$ & $1,03 a$ \\
\hline 20 & P3 & $49.665 \mathrm{~b}$ & $6.125 \mathrm{a}$ & $22,13 a$ & $4,73 a$ & $4,25 a$ & $0,60 a$ \\
\hline 20 & P6 & $58.037 \mathrm{a}$ & $5.033 \mathrm{~b}$ & $34,93 a$ & $10,30 a$ & $6,23 a$ & $1,13 a$ \\
\hline
\end{tabular}


$\mathrm{Hg}$ pada tanaman. Akumulasi Hg yang tinggi pada tajuk lebih diutamakan untuk tanaman akumulator karena lebih memudahkan memanen $\mathrm{Hg}$ dari atas permukaan tanah (tajuk) dibandingkan dari dalam tanah (akar). Merkuri yang masih tinggi terkandung dalam akar kurang efektif untuk tujuan fitoremediasi. Karena itu salah satu kriteria tanaman hiperakumulator apabila tanaman potensi akumulasi dalam tajuk jauh melebihi akumulasi dalam akar, yang dicerminkan dengan rasio kandungan logam tajuk/akar lebih dari satu ${ }^{4)}$. Hal ini mencerminkan bahwa sistem translokasi unsur dari akar ke tajuk pada tumbuhan hiperakumulator lebih efisien dibandingkan tanaman normal.
Beberapa karakteristik harus dipenuhi suatu jenis tumbuhan hiperakumulator. Karakteristik tumbuhan hiperakumulator adalah : (i) Tahan terhadap logam dalam konsentrasi tinggi pada jaringan akar dan tajuknya; (ii) memiliki laju penyerapan logam yang tinggi dibanding tanaman lain; (iii) Memiliki kemampuan mentranslokasi dan mengakumulasi logam dari akar ke tajuk dengan laju yang tinggi ${ }^{2}$ dan (iv) Secara ideal memiliki potensi produksi biomasa yang tinggi (10). Produksi biomassa yang tinggi diharapkan memberikan kontribusi positif terhadap akumulasi $\mathrm{Hg}$ pada tanaman karena total $\mathrm{Hg}$ yang terakumulasi dalam tanaman merupakan fungsi dari konsentrasi

Tabel 5. Konsentrasi Hg pada tanaman umur 1 bulan setelah tanam (ppm)

\begin{tabular}{|c|c|c|c|c|}
\hline \multicolumn{2}{|c|}{ Perlakuan/Peubah } & \multicolumn{2}{|c|}{ Konsentrasi Hg (ppm) } & \multirow[t]{2}{*}{ Ratio konsentrasi $\mathrm{Hg}$ tajuk/akar } \\
\hline Kelat & Pupuk & Tajuk & Akar & \\
\hline \multicolumn{5}{|c|}{ KIAM B A N G } \\
\hline \multirow[t]{3}{*}{ K0 } & P0 & 46861 & 61202 & 0.766 \\
\hline & P3 & 45066 & 52387 & 0.860 \\
\hline & P6 & 49555 & 35352 & 1.402 \\
\hline \multirow[t]{3}{*}{ K20 } & $\mathrm{P} 0$ & 32836 & 54647 & 0.601 \\
\hline & P3 & 49048 & 25486 & 1.925 \\
\hline & $\mathrm{P} 6$ & 48687 & 21054 & 2.312 \\
\hline \multicolumn{5}{|c|}{ E C E N G } \\
\hline \multirow[t]{3}{*}{ K0 } & $\mathrm{P} 0$ & 18837 & 51322 & 0.367 \\
\hline & P3 & 15118 & 59911 & 0.252 \\
\hline & P6 & 17347 & 59075 & 0.294 \\
\hline \multirow[t]{3}{*}{ K20 } & $\mathrm{P} 0$ & 16134 & 59055 & 0.273 \\
\hline & P3 & 14603 & 60058 & 0.243 \\
\hline & P6 & 13953 & 58833 & 0.237 \\
\hline \multicolumn{5}{|c|}{ GEN JER } \\
\hline \multirow[t]{3}{*}{ K0 } & $\mathrm{P} 0$ & 24659 & 50186 & 0.491 \\
\hline & $\mathrm{P} 3$ & 24010 & 50620 & 0.474 \\
\hline & P6 & 21218 & 53592 & 0.396 \\
\hline \multirow[t]{3}{*}{ K20 } & P0 & 18348 & 55785 & 0.329 \\
\hline & $\mathrm{P} 3$ & 27383 & 47114 & 0.581 \\
\hline & P6 & 24405 & 52829 & 0.462 \\
\hline \multicolumn{5}{|c|}{ PAD I } \\
\hline \multirow[t]{3}{*}{ K0 } & $\mathrm{PO}$ & 22890 & 59351 & 0.386 \\
\hline & P3 & 14759 & 59395 & 0.248 \\
\hline & P6 & 10633 & 58162 & 0.183 \\
\hline \multirow[t]{3}{*}{ K20 } & P0 & 9417 & 58268 & 0.162 \\
\hline & P3 & 7999 & 59339 & 0.135 \\
\hline & P6 & 6517 & 59664 & 0.109 \\
\hline
\end{tabular}


$\mathrm{Hg}$ dan total biomassanya. Nilai Kandungan logam berat pada tanaman merupakan hasil perkalian antara konsentrasi dengan bobot kering tanaman ${ }^{(1,3)}$. Tabel 6 menunjukkan kandungan $\mathrm{Hg}$ pada masing-masing jenis tanaman pada masing-masing perlakuan.

Hasilnya Menunjukkan Bahwa Terhadap Kandungan Hg Pada Tanaman, Perlakuan Pemupukan Dan Kelat Pada Umumnya Mengakibatkan Peningkatan Kandungan Hg Total (Mg) Dibanding Tanpa Pemupukan (Tabel 5). Pengaruh Pemupukan Terhadap Konsentrasi Hg (Ppm) Bervariasi, Tetapi Karena Bobot Kering Dipengaruhi Oleh Pemupukan Maka Kandungan Hg (Hasil Perkalian Konsentrasi Hg Pada Tanaman Dengan Bobot Keringnya) Yang Dapat Diambil Tanaman Terlihat Meningkat Pada Perlakuan Pemupukan. Secara Umum Pemupukan Meningkatkan Kandungan Hg
Yang Dapat Diambil Tajuk, Kecuali Pada Padi Perlakuan P6K0 Yang Mengakibatkan Menurunnya Kandungan Hg Tanaman.

Nilai Ratio Akumulasi Kandungan $\mathrm{Hg}$ Yang Lebih Dari Satu Terdapat Pada Kiambang, Genjer Dan Eceng. Nilai Ratio Tersebut Meningkat Dengan Perlakuan Pemupukan. Berdasarkan Kriteria Yang Harus Dipenuhi Oleh TumbuhanAkumulator Maka Kiambang, Genjer Dan Eceng Dapat Dikategorikan Sebagai Tanaman Berpotensi Sebagai Akumulator Hg. Untuk Mencapai Potensi Yang Lebih Optimal Masih Diperlukan Serangkaian Penelitian Lebih Lanjut, Termasuk Perbaikan Potensi Genetik Dan Potensi Fisiologis Tanaman.

\section{KESIMPULAN}

Hasil Penelitian Menunjukkan Pertumbuhan Ke Empat Jenis Tanaman Yang

Tabel 6. Kandungan $\mathrm{Hg}$ (konsentrasi $\mathrm{Hg} \mathrm{X}$ bobot kering tanaman) saat panen (mg)

\begin{tabular}{|c|c|c|c|c|c|c|}
\hline \multicolumn{2}{|c|}{ Perlakuan/ peubah } & \multirow[b]{2}{*}{$\begin{array}{c}\text { Kand } \mathrm{Hg} \\
\text { tajuk(mg) }\end{array}$} & \multirow[b]{2}{*}{$\begin{array}{l}\text { Kand } \mathrm{Hg} \\
\text { akar(mg) }\end{array}$} & \multirow[b]{2}{*}{$\begin{array}{l}\text { Kand hg } \\
\text { total (mg) }\end{array}$} & \multirow[b]{2}{*}{$\begin{array}{c}\text { Ratio tajuk/ } \\
\text { akar }\end{array}$} & \multirow{2}{*}{$\begin{array}{c}\text { Peningkatan } \\
\text { kandungan } \mathrm{Hg} \text { total } \\
\text { dibanding tanpa } \\
\text { pemupukan }(\%)\end{array}$} \\
\hline Kelat & Pupuk & & & & & \\
\hline \multicolumn{7}{|c|}{ KIAM B A N G } \\
\hline \multirow[t]{3}{*}{ K0 } & P0 & 0,253 & 0,119 & 0,372 & 2.126 & - \\
\hline & $\mathrm{P} 3$ & 0,321 & 0,075 & 0,396 & 4.280 & 106.45 \\
\hline & P6 & 0.399 & 0.080 & 0,479 & 4.988 & 128.76 \\
\hline \multirow[t]{3}{*}{ K1 } & PO & 0.188 & 0,111 & 0,299 & 1.694 & 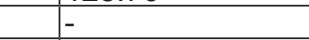 \\
\hline & $\mathrm{P} 3$ & 0.368 & 0,059 & 0,427 & 6.237 & 142.81 \\
\hline & P6 & 0,360 & 0,034 & 0,394 & 10.588 & 131.77 \\
\hline \multicolumn{7}{|c|}{ E C E N G } \\
\hline \multirow[t]{3}{*}{ K0 } & PO & 0.035 & 0,053 & 0,088 & 0.66 & - \\
\hline & $\mathrm{P} 3$ & 0.075 & 0,069 & 0,144 & 1.087 & 163.63 \\
\hline & $\mathrm{P} 6$ & 0,051 & 0.056 & 0,107 & 0.911 & 121.59 \\
\hline \multirow[t]{3}{*}{ K1 } & PO & 0.049 & 0,070 & 0,119 & 0.700 & 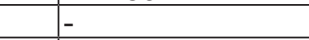 \\
\hline & P3 & 0.056 & 0,056 & 0,112 & 1.000 & 94.12 \\
\hline & P6 & 0,072 & 0,085 & 0,157 & 0.847 & 131.93 \\
\hline \multicolumn{7}{|c|}{ GEN JER } \\
\hline \multirow[t]{3}{*}{ K0 } & P0 & 0.059 & 0,047 & 0,106 & 1.255 & - \\
\hline & $\mathrm{P} 3$ & 0,154 & 0,103 & 0,257 & 1.495 & 242.45 \\
\hline & P6 & 0,124 & 0,07 & 0,194 & 1.771 & 183.02 \\
\hline \multirow[t]{3}{*}{ K1 } & $\mathrm{PO}$ & 0,046 & 0,083 & 0,129 & 0.554 & 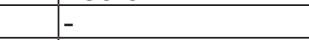 \\
\hline & P3 & 0.140 & 0,054 & 0,194 & 2.593 & 150.39 \\
\hline & $\mathrm{P} 6$ & 0.160 & 0,044 & 0,204 & 3.636 & 158.14 \\
\hline \multicolumn{7}{|c|}{ PADI } \\
\hline \multirow[t]{3}{*}{ K0 } & P0 & 0,073 & 0,045 & 0,118 & 1.622 & - \\
\hline & P3 & 0,111 & 0,104 & 0,215 & 1.067 & 182.20 \\
\hline & $\mathrm{P} 6$ & 0,034 & 0,040 & 0,074 & 0.850 & 62.71 \\
\hline \multirow[t]{3}{*}{$\mathrm{K} 1$} & PO & 0,031 & 0,060 & 0,091 & 0.517 & - \\
\hline & P3 & 0,034 & 0,036 & 0,070 & 0.945 & 76.92 \\
\hline & P6 & 0,041 & 0,064 & 0,105 & 0.641 & 115.38 \\
\hline & & & & & & \\
\hline
\end{tabular}


Diuji Berbeda Nyata. Pengaruh Perlakuan Kelat Terhadap Pertumbuhan Tanaman Tidak Berbeda Nyata, Sedangkan Pengaruh Perlakuan Pemupukan Berbeda Nyata. Konsentrasi Hg Yang Dapat Diserap Tanaman Bervariasi Pada Berbagai Perlakuan Yang Diberikan. Perlakuan Pemupukan Dapat Meningkatkan Bobot Kering Tajuk Tanaman Dengan Nyata Sehingga Hasil Akhirnya Dapat Meningkatkan Kandungan Merkuri Yang Diakumulasi Tanaman. Berdasarkan Kriteria Tanaman Akumulator Yakni Ratio Kandungan Hg Di Tajuk Dan Akar Yang Lebih Satu Maka Kiambang Merupakan Jenis Yang Paling Potensial Sebagai Akumulator Merkuri Diikuti Genjer Dan Eceng.

\section{DAFTAR PUSTAKA}

1. Baker, AJM, RD Reeves, ASM Hajar. 1994. Heavy metal accumulation and tolerance in British populations of the metallophyte Thlaspi caerulescens J.\&C. Presl (Brassicaceae). New Phytol 127:61-68.

2. Brown SL, RL Chaney, JS Angle, JM Baker.1995. Zinc and cadmium uptake by hyperaccumulator Thlaspi caerulescens grown in nutrient solutionn. Soil Sci.Soc.Am.J 59:125133.

3. Chaney RL, SL Brown, YM Li, JS Angle, F Homer, C Green. 1995. Potential use of metal hyperaccumulators. Mining Environ Management 3(3):9-11.

4. Gabbrielli R, C Mattioni, O Vergnano. 1991. Accumulation mechanisms and heavy metal tolerance of a nickel hyperaccumulator. J Plant Nutr 14:1067-1080.

5. Henry, JR. 2000. An overview of the Phytoremediation of lead and mercury. National Network of Environmental Management Studies Fellow. May-
August 2000. Prepared for US Environmental Protection Agency. Office of Solid Waste and Emergency Response. Technology Innovation Office. Washington DC. http://clu-in. org.

6. Juhaeti, T., N Hidayati, S Hidayat, $\mathrm{F}$ Syarif dan M Harapini. 2007. Laporan Final Kegiatan Kompetitif LIPI Tahun 2007.

7. Moreno, FN, CWN Anderson and RB Stewart \& BH Robinson. 2004. Phytoremediation of mercurycontaminated mine tailings by induced plant-mercury accumulation. Environ. Practices 6(2): 165-175.

8. Moreno, F.N, CWN Anderson and RB Stewart. 2005a. Effect of thioligands on plant-Hg accumulation and volatilisation from mercurycontaminated mine tailings. Plant and Soil 275: 233-246.

9. Moreno, FN, CWN Anderson, RB Stewart \& BH Robinson. $2005 b$. Mercury volatilisation and phytoextraction from base-metal mine tailings. Environmental pollution vol. 136: 341-352).

10. Reeves RD. 1992. The hyperaccumulation of nickel by serpentine plants. Di dalam: Backer AJM, Proctor j, Reeves RD (ed). The vegetation of ultramafic (serpentine) soils. Hampshire: Intercept Ltd. HIm 253-227.

11. Salt, DE. 2000. Phytoextraction: Present applications and future promise dalam: Wise D.L, Trantolo D.J, Cichon E.J., Inyang H.I dan Stottmeister U. (Eds.). Bioremediation of Contaminated Soils Marcek Dekker Inc. New York.Basel. hlm 729-743. 